\title{
Correction of soil acidity with shell lime and dolomitic limestone in a Latossolo Vermelho distrófico in Paraná state, Brazil
}

\author{
Corrección de la acidez del suelo con caliza de concha y dolomítica \\ en Latossolo Vermelho distrófico en el estado del Paraná, Brasil \\ Gustavo Soares Wenneck ${ }^{1 *}$, Reni Saath ${ }^{2}$, Danilo César Santi ${ }^{1}$, \\ Nathália de Oliveira Sá2, Larissa Leite de Araújo ${ }^{2}$
}

\begin{abstract}
Soil acidity is a limiting factor for agricultural production, and the correction is carried out by liming, with the variable response with characteristics of the soil and the source used. The study aimed to analyze the effect of liming on a Latossolo Vermelho distrófico (stands for the oxisols in soil taxonomy and Ferralsols in WRB-FAO). The experiment was conducted in a completely randomized design in a $2 \times 2 \times 3$ factorial scheme, with two soil textures (medium and clayey), two types of limestone (dolomitic and shell), and three soil cover conditions (without cover, with corn residues, and with soy residues). Liming carried out considering the chemical characteristics of the soil, the neutralization power of the sources, and the quantity determined by the base saturation method. The data were submitted to analyses of variance, and the means were compared by the Scott-Knott test, with 5\% significance. The acidity correction occurred in less time in clayey soil. The coverage on the soil surface influenced the acidity correction, with a dynamic response concerning the analyzed conditions. Shell and dolomitic lime showed adequate efficiency in correcting acidity in both soil textures, with non-standard differences in conditions.
\end{abstract}

Keywords: remaining biomass, Glycine max, liming, Zea mays.

\section{RESUMEN}

La acidez del suelo es un factor limitante para la producción agrícola y la corrección realizada por encalado, con respuesta variable con las características del suelo y la fuente utilizada. El estudio tuvo como objetivo analizar el efecto del encalado en un Latossolo Vermelho distrófico (significa los oxisoles en taxonomía del suelo y los ferralsoles en WRB-FAO). El experimento se realizó en un diseño completamente al azar en un esquema factorial $2 \times 2 \times 3$, con dos texturas de suelo (media y arcillosa), dos tipos de calizas (dolomítica y concha) y tres condiciones de cobertura del suelo (sin cobertura, con residuos de maíz y con residuos de soja). El encalado se hace considerando las características químicas del suelo, el poder de neutralización de las fuentes y la cantidad determinada por el método de saturación de bases. Los datos fueron sometidos a análisis de varianza y las medias comparadas mediante la prueba de Scott-Knott, con una significancia del 5\%. La corrección de la acidez se produjo en menos tiempo en suelos arcillosos. La cobertura en superficie influyó en la corrección de la acidez, con respuesta dinámica con relación a las condiciones analizadas. La caliza de concha y dolomítica mostraron una adecuada eficiencia en la corrección de la acidez. en ambas texturas del suelo, con diferencias no estándar en las condiciones.

Palabras clave: biomasa remanente, Glycine max, encalado, Zea mays.

\section{Introduction}

Tropical soils have acidity as a natural characteristic, which acts as a limiting factor depending on the availability of nutrients and the development of the root system of plants, requiring correction to support the agricultural production (Martins and Alves, 2015). Soil acidity is caused by water, use of fertilizers with acidifying potential, by mineralization of organic matter, besides the reduction of cations content, such as calcium $(\mathrm{Ca})$, magnesium $(\mathrm{Mg})$, and potassium $(\mathrm{K})$, by leaching and export by plants (Nolla et al., 2015; Caries and Joris, 2016).

In weathered soils, such as oxisols, the presence of organic matter is fundamental for the stability of the system, being favorable for the physical,

\footnotetext{
Program in Agronomy, Universidade Estadual de Maringá (UEM), Maringá, Paraná, Brazil.

2 Departament of Agronomy, Universidade Estadual de Maringá (UEM), Maringá, Paraná, Brazil.

* Corresponding author: gustavowenneck@gmail.com
}

Fecha de Recepción: 10 de Agosto, 2020.

Fecha de Aceptación: 2 de Noviembre, 2020. 
chemical, and biological quality of the soil. Regarding chemical composition, it acts on the adsorption of ions, reducing their leaching (Francisco et al., 2016).

The preservation of the cover on the soil surface is one of the practices recommended in conservationist production systems, such as the no-till system (NT), with reflexes on soil conservation and reducing environmental impacts related to carbon sequestration. (Favarato et al., 2016; Guimarães et al., 2015). As a component of the production system, soil cover can influence soil chemical changes, such as correcting soil acidity, being a dynamic process and varying depending on the characteristics of the material (Nolla et al., 2015; Cunha et al., 2018; Guimarães et al., 2015; Caries e Joris, 2016)

In this sense, the study aimed to analyze the dynamics of acidity correction in a Latossolo Vermelho distrófico of medium and clayey texture with different soil cover, using shell and dolomitic lime.

\section{Material and methods}

The experiment was carried out in a greenhouse at the State University of Maringá (UEM), at $23^{\circ} 25^{\prime} \mathrm{S}, 51^{\circ} 57^{\prime} \mathrm{W}$, and an average altitude of 542 $\mathrm{m}$, in Maringá-PR. It was adopted a completely randomized design in a $2 \times 3 \times 2$ factorial scheme with four replications. Two soil textures (medium and clayey), three soil cover conditions (without cover, with soybean residues, and corn residues), and two types of limestone (dolomitic and shell) were evaluated.

The two soils, Latossolo Vermelho distrófico (Santos et al., 2018) of medium and clayey texture, were collected in an annual crop production area in the $0-0.20 \mathrm{~m}$ layer. They were air-dried, sieved to remove foreign matter, homogenized, and stored in polyethylene containers with a capacity of $1 \mathrm{dm}^{-3}$.

As soil cover, the soil residues of soybean and corn crops were collected in the field, submitted to drying in an air-forced circulation oven $\left(65^{\circ} \mathrm{C}\right.$ for 72 hours), crushed, and distributed on the soil surface in an amount proportional to $3.5 \mathrm{tha}^{-1}$ soy and $20 \mathrm{t} \mathrm{ha}^{-1}$ of corn, according to treatment.

The amount of lime applied was determined by the base saturation method, considering the chemical characterization of the soil (Table 1), characteristics of the adopted corrective sources (shell and dolomitic lime), and expected base saturation of $70 \%$ (V1). It was also considered the quantity proportional to the volume of soil per container. After liming, the soil was moistened weekly until it reached humidity close to the field capacity.

From the second to the eighth month after liming, soil samples were collected, and the $\mathrm{pH}$ was determined using the $\mathrm{KCl}(1 \mathrm{M})$ solution as an extractor as described by Claessen (1997). The data were submitted to the analysis of variance, and the means were grouped using the Scott-Knott test, with a significance of 5\%, using the Sisvar software. (Ferreira, 2019).

\section{Results and discussions}

From the results of variation in the functions of the lime sources (shell and dolomitic lime) and the method adopted, the actions of the progressive process in the Oxisol (LVd) of clayey texture were observed. In the second month after the lime application, the $\mathrm{pH}$ of untreated soil and with crop residues on the surface was higher than 5.7 (Table 2). The higher $\mathrm{pH}$ in soil covered with corn residues may be associated with a rapid decomposition. The correction of soil acidity from the calibration with dolomitic limestone in soils without cover proved to be more efficient, showing higher $\mathrm{pH}$. Constant values in soils with soybean residues from the third to the sixth month were observed. In the soil with corn residues, the $\mathrm{pH}$ values were lower after the second month after calibration (Table 2).

The reaction of the lime in the soil and the response in the adequacy of acidity correlated with the reactivity of the material and leaching of causes in depth more evident in sandy soils (Centeno et al., 2017). Reactivity is also related to the granulometry of the lime; for example, the liquid lime, which has microparticles, has a faster effect on the acidity correction, but it does not have a residual effect (Mantovanelli et al., 2019).

In the third month, in all cover conditions and limestone sources, the soil $\mathrm{pH}$ was higher than 5.5, indicating that the dynamics of chemical and biological actions provided the maintenance of the soil in conditions favorable to agricultural production. Although it has no direct effect on the physical characteristics of the soil, such as resistance to penetration (Oliveira et al., 2017), a calibration to correct the $\mathrm{pH}$ of the soil increases the availability of nutrients and favors the plant development, including the root system, influencing it indirectly (Guimarães et al., 2015; Centeno et al., 2017). 
Table 1. Soil chemical characterization.

\begin{tabular}{lccccccccccc}
\hline \multirow{2}{*}{$\begin{array}{c}\text { Soil } \\
\text { texture }\end{array}$} & \multicolumn{2}{c}{$\mathrm{pH}$} & $\mathrm{Al}$ & $\mathrm{H}+\mathrm{Al}$ & $\mathrm{Ca}$ & $\mathrm{Mg}$ & $\mathrm{K}$ & $\mathrm{SB}^{1}$ & $\mathrm{CEC}^{2}$ & $\mathrm{P}$ & $\mathrm{C}$ \\
\cline { 2 - 10 } & $\mathrm{H}_{2} \mathrm{O}$ & $\mathrm{KCl}$ & \multicolumn{7}{c}{$-\mathrm{cmol}_{\mathrm{c}} \mathrm{dm}^{-3}-$} \\
Medium & 4.5 & 4.0 & 1.71 & 7.59 & 0.20 & 0.06 & 0.03 & 0.29 & 7.88 & 3.16 & 23.94 \\
Clayey & 5.0 & 4.7 & 0.28 & 3.30 & 0.85 & 0.36 & 0.04 & 1.25 & 4.55 & 2.60 & 11.57 \\
\hline
\end{tabular}

${ }^{1} \mathrm{SB}$ : sum of bases; ${ }^{2} \mathrm{CEC}$ : Cation Exchange Capacity.

Table 2. Soil pH by $\mathrm{KCl}$ method after shell and dolomitic lime application, in a Latossolo Vermelho distrófico with medium clayey under different soil cover.

\begin{tabular}{|c|c|c|c|c|c|c|c|c|}
\hline \multirow{2}{*}{ Soil cover } & \multirow{2}{*}{ Lime } & \multicolumn{7}{|c|}{ Months after lime application } \\
\hline & & $2^{\text {nd }}$ & $3^{\text {rd }}$ & $4^{\text {th }}$ & $5^{\text {th }}$ & $6^{\text {th }}$ & $7^{\text {th }}$ & $8^{\text {th }}$ \\
\hline Corn & Shell & $5.42 \mathrm{cB}$ & $5.61 \mathrm{bB}$ & $5.71 \mathrm{bB}$ & $5.75 \mathrm{bC}$ & $5.82 \mathrm{aB}$ & $5.92 \mathrm{aB}$ & $5.90 \mathrm{aB}$ \\
\hline Corn & Dolomitic & $5.50 \mathrm{cB}$ & $5.78 \mathrm{bB}$ & $5.73 \mathrm{bB}$ & $5.90 \mathrm{bB}$ & $6.12 \mathrm{aA}$ & $6.39 \mathrm{aA}$ & $5.91 \mathrm{bB}$ \\
\hline Corn & - & $5.11 \mathrm{aC}$ & $5.00 \mathrm{aC}$ & $5.10 \mathrm{aC}$ & $5.03 \mathrm{aD}$ & $4.99 \mathrm{aD}$ & $4.92 \mathrm{aD}$ & $4.95 \mathrm{aD}$ \\
\hline Soybean & Shell & $5.32 \mathrm{bB}$ & $6.01 \mathrm{aA}$ & $5.89 \mathrm{aB}$ & $5.68 \mathrm{bC}$ & $5.62 \mathrm{bB}$ & $5.58 \mathrm{aB}$ & $5.48 \mathrm{bC}$ \\
\hline Soybean & Dolomitic & $5.64 \mathrm{bA}$ & $5.59 \mathrm{bB}$ & $5.79 \mathrm{bB}$ & $5.79 \mathrm{bC}$ & $5.99 \mathrm{aB}$ & $6.19 \mathrm{aA}$ & $6.02 \mathrm{aA}$ \\
\hline Soybean & - & $5.33 \mathrm{aB}$ & $5.39 \mathrm{aC}$ & $5.27 \mathrm{aC}$ & $5.12 \mathrm{aD}$ & $5.22 \mathrm{aC}$ & $5.34 \mathrm{aC}$ & $5.13 \mathrm{aC}$ \\
\hline- & Shell & $5.89 \mathrm{bA}$ & $5.88 \mathrm{bB}$ & $6.05 \mathrm{aA}$ & $6.14 \mathrm{aA}$ & $6.26 \mathrm{aA}$ & $6.21 \mathrm{aA}$ & $6.09 \mathrm{aA}$ \\
\hline- & Dolomitic & $5.79 \mathrm{bA}$ & $6.03 \mathrm{bA}$ & $6.16 \mathrm{aA}$ & $6.15 \mathrm{aA}$ & $6.11 \mathrm{aA}$ & $5.87 \mathrm{bB}$ & $5.76 \mathrm{bB}$ \\
\hline- & - & $5.42 \mathrm{aB}$ & $5.43 \mathrm{aC}$ & $5.43 \mathrm{aC}$ & $5.35 \mathrm{bD}$ & $5.31 \mathrm{bC}$ & $5.33 \mathrm{bC}$ & $5.26 \mathrm{bC}$ \\
\hline \multicolumn{2}{|c|}{$\mathrm{CV}(\%)$} & 3.92 & 5.79 & 8.61 & 7.15 & 3.17 & 3.13 & 6.17 \\
\hline
\end{tabular}

* Means followed by different lowercase letters in the lines and uppercase letters in the columns belong to different groups by the Scott-Knott test.

About liming over soybean residues, from the fifth month onwards, the shell limestone showed a downward trend, reaching a $\mathrm{pH}$ value of 5.48 in the eighth month, whose reduction may indicate the re-acidification process. Regardless of the soil texture, there was variation in the soil $\mathrm{pH}$ values in the treatments without application of lime during the period, observing in the Latossolo Vermelho distrófico with a clay texture oscillations of $3.13 \%$ in the $\mathrm{pH}$ values (Table 2) and $2.74 \%$ in the soil with medium texture (Tables 3).

When we analyzed the effects of liming using shell lime in medium texture, it found that the soil with soy residues on the surface presented $\mathrm{pH}$ values significantly lower than those of corn residues in the $2^{\text {nd }}, 3^{\text {rd }}, 6^{\text {th }}, 7 \mathrm{t}^{\mathrm{th}}$, and $8^{\text {th }}$ month. Based on the assumption that the source of the limestone and the soil texture has a direct interference in the corrective indexes, the indexes suggest actions of dynamic processes in the soil due to the management and residues of the cover plants. When the residues are decomposing, they alter the physical and chemical attributes of the soil, whose decomposition rates are influenced by climatic variables, lignin/cellulose contents, $\mathrm{C}: \mathrm{N}$ ratio, and characteristics of the lime. This hypothesis is supported by the observations that the constitution of the correctives influences changes in the contents of chemical components and on the soil microbiology (Barth et al., 2018), with the dynamic interaction between the components involved.

Comparing the soil textures, in the soil of medium texture, $\mathrm{pH}$ values higher than 5.5 were obtained from the fourth month (Table 3), while in the soil with clayey texture in the second month after liming (Table 2), with responses associated with characteristics intrinsic to the soil, as cation exchange capacity (Centeno et al., 2017).

The effects of liming are residual, reaching deeper layers without incorporation, even in degraded areas and with reflections for years after the application (Joris et al., 2016), following the precepts of cultivation in conservationist systems. In medium-textured soils, the action of lime in depth can be favored by growing grasses (Nolla et al., 2015). 
Table 3. Soil $\mathrm{pH}$ by $\mathrm{KCl}$ method after shell and dolomitic lime application, in a

Latossolo Vermelho distrófico with medium texture under different soil cover.

\begin{tabular}{|c|c|c|c|c|c|c|c|c|}
\hline \multirow{2}{*}{ Soil cover } & \multirow{2}{*}{ Lime } & \multicolumn{7}{|c|}{ Months after lime application } \\
\hline & & $2^{\text {nd }}$ & $3^{\text {rd }}$ & $4^{\text {th }}$ & $5^{\text {th }}$ & $6^{\text {th }}$ & $7^{\text {th }}$ & $8^{\text {th }}$ \\
\hline Corn & Shell & $5.15 \mathrm{cA}$ & $5.48 \mathrm{bA}$ & $5.56 \mathrm{bA}$ & $5.97 \mathrm{bA}$ & $6.24 \mathrm{aA}$ & $6.56 \mathrm{aA}$ & $6.17 \mathrm{aA}$ \\
\hline Corn & Dolomitic & $4.83 \mathrm{bB}$ & $5.21 \mathrm{bB}$ & $5.59 \mathrm{aA}$ & $5.71 \mathrm{aA}$ & $6.00 \mathrm{aB}$ & $6.56 \mathrm{aA}$ & $6.36 \mathrm{aA}$ \\
\hline Corn & - & $4.23 \mathrm{aC}$ & $4.15 \mathrm{aC}$ & $4.07 \mathrm{aB}$ & $4.06 \mathrm{aB}$ & $4.04 \mathrm{aC}$ & $4.02 \mathrm{aD}$ & $3.92 \mathrm{aD}$ \\
\hline Soybean & Shell & $4.73 \mathrm{bB}$ & $4.93 \mathrm{bB}$ & $5.45 \mathrm{bA}$ & $5.71 \mathrm{aA}$ & $5.75 \mathrm{aB}$ & $5.79 \mathrm{aC}$ & $5.87 \mathrm{aB}$ \\
\hline Soybean & Dolomitic & $4.87 \mathrm{bB}$ & $4.97 \mathrm{bB}$ & $5.11 \mathrm{bA}$ & $5.55 \mathrm{aA}$ & $5.84 \mathrm{bB}$ & $6.07 \mathrm{aB}$ & $6.04 \mathrm{aA}$ \\
\hline Soybean & - & $4.06 \mathrm{aC}$ & $4.00 \mathrm{aC}$ & $4.13 \mathrm{aB}$ & $4.14 \mathrm{aB}$ & $4.08 \mathrm{aC}$ & $4.02 \mathrm{aD}$ & $4.07 \mathrm{aC}$ \\
\hline- & Shell & $5.30 \mathrm{bA}$ & $5.77 \mathrm{bA}$ & $5.85 \mathrm{bA}$ & $6.35 \mathrm{aA}$ & $6.52 \mathrm{aA}$ & $6.60 \mathrm{aA}$ & $6.40 \mathrm{aA}$ \\
\hline- & Dolomitic & $5.26 \mathrm{bA}$ & $5.36 \mathrm{bA}$ & $5.47 \mathrm{bA}$ & $5.78 \mathrm{aA}$ & $6.34 \mathrm{aA}$ & $6.18 \mathrm{aB}$ & $6.08 \mathrm{aA}$ \\
\hline- & - & $4.01 \mathrm{aC}$ & $4.14 \mathrm{aC}$ & $3.95 \mathrm{aB}$ & $3.92 \mathrm{aB}$ & $3.91 \mathrm{aC}$ & $4.08 \mathrm{aD}$ & $3.90 \mathrm{aD}$ \\
\hline \multicolumn{2}{|c|}{ CV (\%) } & 2.96 & 2.98 & 2.36 & 2.10 & 2.79 & 2.40 & 4.47 \\
\hline
\end{tabular}

* Means followed by different lowercase letters in the lines and uppercase letters in the columns belong to different groups by the Scott-Knott test.

Splitting the amount of lime can increase the residual effect, adjusting $\mathrm{pH}$, base saturation, and aluminum in deeper soil layers (Rheinheimer et al., 2018). However, small amounts can have localized results and a restricted residual effect (Caries and Joris, 2016). Parizotto et al. (2018), analyzing the efficiency of the application of shell limestone in the sowing rows of beans, soybeans, corn, and wheat, did not find significant effects on the mass of grains when using limestone.

Considering the application with quantity according to the base saturation method and the total neutralization power of the correctives, liming with shell and dolomitic lime satisfied the $\mathrm{pH}$ correction in Latossolo Vermelho distrófico with medium and clayey textured, with the soil coverage influencing the process.

\section{Conclusions}

The dynamics of the $\mathrm{pH}$ values detected in the Latossolo Vermelho distrófico with clayey textured showed the shortest time for acidity correction.

Shell and dolomitic limestone showed an adequate corrective effect, regardless of soil texture.

The coverage of the soil surface influenced the correction of acidity after liming.

\section{Acknowledgements}

This study was financed in part by the Coordenação de Aperfeiçoamento de Pessoal de Nível Superior - Brasil (CAPES) - Finance Code 001.

\section{Literature Cited}

Barth, V.P.; Reardon, C.L.; Coffey, T.; Klein, A.M.; McFarland, C.; Huggins, D.R.; Sullivan, T.S.

2018. Stratification of soil chemical and microbial properties under no-till after liming. Applied Soil Ecology, 130: 169-177.

Caries, E.F.; Joris, H.A.W.

2016. Uso de corretivos granulados na agricultura. IPNI

Informações Agronômicas, 154, 17-21.

Centeno, L.N.; Guevara, M.D.F.; Cecconello, S.T.; Sousa, R.O.D.; Timm, L.C.

2017. Textura do solo: conceitos e aplicações em solos arenosos. Revista Brasileira de Engenharia e Sustentabilidade, 4 (1): 31-37.

Claessen, M.E.C.; Barreto, W.O.; Paula, J.L.; Duarte, M.N. 1997. Manual e métodos de análise de solo. second ed. EMBRAPA-CNPS. Rio de Janeiro, Brazil. 212 p.
Ferreira, D.F.

2019. SISVAR: a computer analysis system to fixed effects Split plot type designs. Revista Brasileira de Biometria, 37 (4); 529-535.

Frohlich, W.F.; Kimura, M.T.; Amaral, J.L.; Medeiros, M.O. 2017. Influência de corretivos incorporados ao solo sobre a população do percevejo castanho-das-raízes Scaptocoris carvalhoi Becker, 1967 (Hemiptera Cydnidae). Biodiversidade, 16 (2): 86-97.

Guimarães, T.M.; Carmeis Filho, A.C.A.; Costa, C.H.M.

2015. Efeito da calagem no estoque de carbono do solo em sistema de semeadura direta. Journal of Agronomic Sciences, 4:71-90.

Joris, H.A.W.; Caires, E.F.; Scharr, D.A.; Bini, A.R.; Haliski, A.

2016. Liming in the conversion from degraded pastureland to a no-till cropping system in Southern Brazil. Soil and Tillage Research, 162: 68-77. 
Mantovanelli, B.C.; Santana, A.C.A.; Rezende, J.S.; Dantas, M.K.L.; Oliveira, E.C.A.

2019. Calcário líquido e convencional na correção da acidez ativa de solos com diferentes texturas. Revista EDUCAmazônia, 23 (2): 125-139.

Mantovani, A; Felicio, T.P.; Zilio, M.; Menosso, A.; Bulla, P.; Mecabô, D.P.; Miotto, P.C.M.

2017. Atributos químicos do solo decorrentes da aplicação em superfície de gesso e calcário. Scientific Electronic Archives, 10(5): 35-43.

Martins, J.D.L.; Alves, M.S.

2015. Substâncias húmicas da matéria orgânica e adsorção de fósforo em solos tropicais. Journal of Agronomic Sciences, 4: 232-245.

Nolla, A. Quiqui, E.M.D.; Ferreira, G.A.; Muniz, A.S.; Fogaça, S.Z.

2015. Amostragem do solo e fatores responsáveis pela acidez do solo: caracterização, critérios e estratégias para correção. Journal of Agronomic Sciences, 4: 91-106.
Oliveira, M.P.; Roque, C.G.; Borges, M.C.R.Z.; Oliveira, R.P.; Nogueira, K.B.

2017. Efeito residual da gessagem e calagem na resistência à penetração obtida com dois penetrômetros em diferentes sistemas de manejo. Revista de Agricultura Neotropical, 4 (1): 58-64.

Parizotto, C.; Pandolfo, C.M.; Veiga, M.

2018. Calcário de conchas, calcário calcítico e gesso na linha de semeadura e seu efeito sobre o rendimento de grãos das culturas. Unoesc \& Ciência, 9(2): 115-120.

Rheinheimer, D.S.; Tiecher, T.; Gonzatto, R.; Zafar, M.; Brunetto, G.

2018. Residual effect of surface-applied lime on soil acidity properties in a long-term experiment under no-till in a Southern Brazilian sandy Ultisol. Geoderma, 313: 7-16.

Santos, H.G.; Jacomine, P.K.T.; Anjos, L.H.C.; Oliveira, V.Á.; Lumbreras, J.F.; Coelho, M.R.; Almeida, J.A.; Araújo Filho, J.C.; Oliveira, J.B.; Cunha, T.J.F.

2018. Sistema Brasileiro de Classificação de Solos. 5. ed. EMBRAPA. 353 p. 
